Agro-Science Journal of Tropical Agriculture, Food, Environment and Extension Volume 20 Number 2 (April 2021) pp. $37-41$

ISSN 1119-7455

\title{
SPECIES ENUMERATION AND DIVERSITY OF FIRE EXPERIMENTAL PLOT AT OLOKEMEJI FOREST RESERVE, OGUN STATE, NIGERIA
}

\author{
Oloketuyi A.J., Akinyemi O.D., "Taiwo D.M., Jeminiwa O.R. and Ayodele A.A. \\ Department of Forest Conservation \& Protection, \\ Forestry Research Institute of Nigeria, Ibadan, Oyo State, Nigeria \\ *Corresponding author's email: taidamar20@gmail.com
}

\begin{abstract}
The fire experimental plot of a total landed area of 0.174 ha was divided into three equal parts designated Plot A, Plot B and Plot C, corresponding to the early burnt, the late burnt and the control plot, respectively. Out of the 15 species of trees identified, six species belong to Fabaceae-Mimosoideae family and other families represented are Combretaceae, Meliaceae, Lamiaceae, Rubiaceae, Anacardiaceae, Urtiaceae and Sapotaceae. Gmelina arborea was the most abundant species and it was found in plot $A, B$ and $C$. The diversity indices enumerated were Dominance index, Simpson index, Shannon index or diversity index and evenness index. Plot Chad the highest abundance (species count), followed by Plot A and Plot B. While Plot B depicted a high dominance, dominance was low in Plot $A$ and lowest in Plot $C$. This means that a particular species was dominating Plot B, which was Gmelina arborea. This Gmelina arborea also dominated Plot A but to a lesser extent compared to Plot B. Plot C was richer in species than Plot A and Plot B. The Shannon index was low across the three plots, but considerably highest in Plot $C$. Evenness index was moderate at Plot C, implying that there was an even distribution of tree species in Plot C, while evenness was low at Plot A and Plot B. Comparing the present data with the older data, it is clear that the fire experimental plot has undergone deforestation over the years, which requires urgent attention and reforestation.
\end{abstract}

Key words: cluster, dendogram, deforestation, burning, richness

\section{INTRODUCTION}

Fire is a fundamental factor on ecosystem functioning and as a major ecological driver of vegetation changes (Attiwill, 1994; Moreno and Oechel, 1994), by modelling landscapes and contributing to maintain habitat heterogeneity and biological diversity (Moreira et al., 2001; Blondel et al., 2010). Given the very strong effect of fire on vegetation, plant distribution and ecosystem function could likely be more heavily affected by the on-going modifications in fire regime consequent to global changes than by the direct effect of climate changes (Pausas and Fernández-Muñoz, 2012). In addition to natural causes of ignition, prescribed burning was one of the management tools commonly used by man (Lloret and Marí, 2001).

The oldest and best known fire experimental plot in West Africa was established in the derived forest savanna ecotone of the Olokemeji Forest Reserve in Ogun State, Nigeria in the year 1889. An extremely simple design became the prototype of several similar fire experiments in other territories. Three small plots laid down in open grassy tree savannah in 1929 were enumerated, clear-felled, and then treated annually, the first plot was named as Plot A where early burning takes place in the early dry season, the second plot was called Plot B where late burning takes place, while the last plot was named as Plot C which is protected from fire and other disturbance.
Re-enumerated 28 years after establishment (after 1889), the protected plot had developed into dense young closed forest rich in fire-tender species derived from existing forest nearby, the grassy ground cover had almost disappeared, and a species of forest grass was invading. The late burned plot had been held at the open tree savannah stage, and the early burned plot was intermediate between the other two, with patches of dense forest expanding into the grass which was becoming thin and increasingly difficult to burn (Charter and Keay, 1960).

Assessment of forest species composition and diversity is essential in understanding the status of tree population, regeneration and diversity for conservation purposes (Mishra et al., 2013; Adubasim et al., 2018). Forest structure mainly depends on such factors as the nature of ecosystem, species composition and woody species dynamics in a particular area. Understanding of woody species composition and diversity in a given forest ecosystem is crucial for the successful planning and implementation of conservation activities (Malik et al., 2014, Malik and Bhatt, 2015). The present study was carried out to understudy the species composition and diversity of trees occurring in the Fire Experimental plots of Olokemeji Forest Reserve at Ogun State of Nigeria after 130 years of its establishment.

Please cite as: Oloketuyi A.J., Akinyemi O.D., Taiwo D.M., Jeminiwa O.R. and Ayodele A.A. (2021). Species enumeration and diversity of fire experimental plot at Olokemeji Forest Reserve, Ogun State, Nigeria. Agro-Science, 20 (2), 37-41. DOI: https://dx.doi.org/10.4314/as.v20i2.6 


\section{MATERIALS AND METHODS}

\section{Study Site}

Olokemeji forest reserve occupies a total land area of $58.88 \mathrm{~km}^{2}$. The reserve, which was established in 1899 is the second forest reserve in Nigeria. The forest reserve is situated between Latitude $7^{\circ} 25^{\prime} \mathrm{N}$ and $7^{\circ} 39^{\prime} \mathrm{N}$ and Longitude $3^{\circ} 32^{\prime} \mathrm{E}$ to $3^{\circ} 44^{\prime} \mathrm{E}$. The site lies approximately $32 \mathrm{~km}$ west of Ibadan, and 35 $\mathrm{km}$ north-east of Abeokuta.

Olokemeji Fire Experimental Plot was established in 1929 for the purpose of fire tracing. Three plots were established within the fire experimental plot and were designated Plot A (early burnt), Plot B (late burnt) and Plot C (protected). The investigation plots are bordered by plantations of Gmelina arborea, Dalbergia sisso and Senna siamea. The physical features, climate and vegetation of the reserve have been described by Hopkins (1962).

\section{Data Collection}

\section{Sampling technique}

All data was collected in the month of April 2019. Total enumeration of trees with diameter at breast height $(\mathrm{DBH})$ greater than or equal to $10 \mathrm{~cm}$ girth was assessed for this study. The botanical name of each tree stand encountered in each sub-plot which was equal or above $10 \mathrm{~cm}$ DBH was recorded. Each tree was recorded fully in the field with extra effort made not to omit any eligible tree in a plot.

\section{Data Analysis}

The data collected were analysed for abundance and species diversity. Species diversity was obtained from diversity indices using Paleontological statistics software (PAST 2.14) (Hammer, 2011). The following parameters were taken into consideration from the diversity index analysis.

\section{Abundance}

Species abundance is used to measures the quantity or number of each species and families in a particular quadrat/plot (Areghore, 2009):

$$
\mathrm{Pi}=\frac{\mathrm{Ni}}{\mathrm{N}}
$$

with $\mathrm{Ni}$ being the abundance of the $\mathrm{i}$-th species in the sample, and $N$ the total number of individuals.

\section{Dominance}

This is a measure of the prevalence of a particular species in relation to other species in an ecosystem. It shows the species with superior competitive ability to others regarded as inferior based on competition (Stephane et al., 2009). It is the most of the population in a community and the effect on any population is mainly influenced by the species of high dominance. It usually ranges from zero to one in value where one signifies high dominance.

\section{Species Richness}

It measures the number of individual species and their abundance in an ecosystem. It shows the richness of a species in a habitat in relation to total species present. Its value ranges from zero (low richness) to one (completely rich in species). Species richness was computed using the procedure outlined by Spellerberg (1991) and Magurran (2004) as used by Oluwatosin and Jimoh (2016):

$$
D=\frac{S}{\sqrt[2]{n}}
$$

where $D$ is species richness (Margalef index), $S$ is the total number of species, and $n$ is the total number of individuals.

\section{Evenness}

It is the relative abundance of species per unit area. This was used to measure the similarity of relative abundance of species within sample plots. It was estimated with the Pielou's evenness index:

$$
J=\frac{H}{S}
$$

where J represents Pielou's evenness index, $\mathrm{H}=$ Shannon diversity index and $\mathrm{S}$ isspecies richness as previously defined (Hopper et al., 2005).

\section{Shannon Wiener}

This is a measure proposed by Claude Shannon and accounts for both abundance and eveenness of species present in an ecosystem (Kent and Coker, 1992; Olubode et al., 2011). It measures overall community characteristics. It usually ranges from one to infinity where two and above signifies high random of species occurrence in an ecosystem.

$$
H=-\sum_{j=1}^{r} p_{j} \ln p_{j}
$$

$H$ is value of $\mathrm{S}-\mathrm{W}$ diversity index, $\bullet$ pi is proportion of individuals in the $i^{\text {th }}$ species, $\cdot \ln$ is natural logarithm, and $\bullet \mathrm{s}$ is number of species in community.

\section{RESULTS}

\section{Species Composition of Woody Flora}

Out of 165 tree stands enumerated for this study, 15 species were found belonging to nine families out of which family Fabaceae-Mimosoideae had the highest number of species, the six species belonging to family Fabaceae-Mimosoideae were Dalbergia sisso, Pterocarpous erinaceous, Albizia lebbeck, Acacia spania, Afzelia africana and Parkia biglobosa. This is followed by family Combretaceae which has two species Lannea egregia and Anogeissus leiocarpus. Other families represented were; Anacardiaceae, Lamiaceae, Malvaceae, Meliaceae, Rutaceae, Sapotaceae and Urticaceae. 
Table 1: Tree species abundance of Olokemeji fire experimental plot

\begin{tabular}{|c|c|c|c|c|}
\hline Species & Families & Plot A & Plot B & Plot C \\
\hline Lannea egregia Engl. \& K. Krause & Anacardiaceae & 2 & & \\
\hline Anogeissus leuocarpa (DC.) Guill. \& Perr. & Combretaceae & 1 & 3 & 3 \\
\hline Terminalia superba Engl. \& Diels & Combretaceae & 1 & & 4 \\
\hline Dalbergia sisso $D C$. & Fabaceae-Mimosoideae & 12 & 5 & 1 \\
\hline Pterocarpous erinacious Poir. & Fabaceae-Mimosoideae & 1 & & 1 \\
\hline Albizia lebbeck (L.) Benth. & Fabaceae-Mimosoideae & 1 & & \\
\hline Acacia spania Pedley & Fabaceae-Mimosoideae & & 3 & 2 \\
\hline Afzelia africana Persoon & Fabaceae-Mimosoideae & & & 5 \\
\hline Parkia biglobosa (Jacq.) R.Br. Ex G.Don & Fabaceae-Mimosoideae & & & 3 \\
\hline Gmelina arborea Roxb.ex Sm & Lamiaceae & 25 & 43 & 8 \\
\hline Hildeglidia barteri (Mast.) Kosterm & Malvaceae & & & 7 \\
\hline Pseudocedra kotschyi Harms & Meliaceae & 4 & & 1 \\
\hline Zanthoxyllum (De Wild) & Rutaceae & & & 1 \\
\hline Vitelleria paradoxa C.F. Gaertn. & Sapotaceae & & & 2 \\
\hline Microdesmis puberula Hook. F. ex. Planch & Urticaceae & & & 26 \\
\hline Total & & 47 & 54 & 64 \\
\hline
\end{tabular}

Plot $\mathrm{C}$ has the highest number of species just as expected of a plot protected from burning and other disturbances (Table 1).

\section{Species Diversity of the Woody Flora Olokemeji Fire Experimental Plot}

Among the three plots enumerated in the fire experimental plot of Olokemeji forest reserve, Plot $\mathrm{C}$ has the highest species abundance this is closely followed by Plot B and Plot A had the least species abundance. This is also applicable to the number of species enumerated in each of the plots with Plot $\mathrm{C}$ having the highest number of species among the rest.

However, Plot B recorded the highest dominance index at 0.63 which means there is a particular species dominating Plot B (Gmelina arborea), dominance index is low for Plot A (0.36) and Plot C (0.20).

The highest Simpson index was recorded at Plot C (0.80) which was closely followed by Plot A (0.64) which is moderately rich and the least species richness recorded among the plots was found in Plot $\mathrm{B}$ as 0.37 as shown in Table 2 and Figure 1.
Low Shanon or diversity index was recorded for three plots. The evenness index was low in Plots A and $\mathrm{B}$, while a moderate evenness index was recorded in Plot $\mathrm{C}$, this could be as a result of the protected nature of the plot.

\section{Cluster Dendogram of Tree Species in the Fire Experimental Plot of Olokemeji Forest Reserve} The dendogram as shown in Figure 2 depicts the relationship among the tree species population based on similarities and dissimilarities (Euclidean distance).

The dendogram showed three major clusters, which are closely related while other stand-alone species are highly dissimilar to the clusters. Gmelina arborea being the most dissimilar species as a result of having the farthest Euclidean distance from the rest of the clusters. Microdesmis puberula also had a wide range of dissimilarity when compared to the other clusters which are closely knitted which depicts the close relationship among species found in the fire experimental plot of Olokemeji forest reserve, the closer the linkage, the closer the similarities among the species.

Table 2: Tree species diversity indices of fire experimental plot of Olokemeji Forest Reserve, Ogun State, Nigeria

\begin{tabular}{lccc}
\hline Diversity Indices & Plot_A & Plot_B & Plot_C \\
\hline Taxa_S & 8 & 4 & 13 \\
Individuals & 47 & 54 & 64 \\
Dominance_D & 0.36 & 0.63 & 0.20 \\
Simpson_1-D & 0.64 & 0.37 & 0.80 \\
Shannon_H & 1.36 & 0.80 & 2.05 \\
Evenness_e`H/S & 0.48 & 0.45 & 0.56 \\
\hline
\end{tabular}




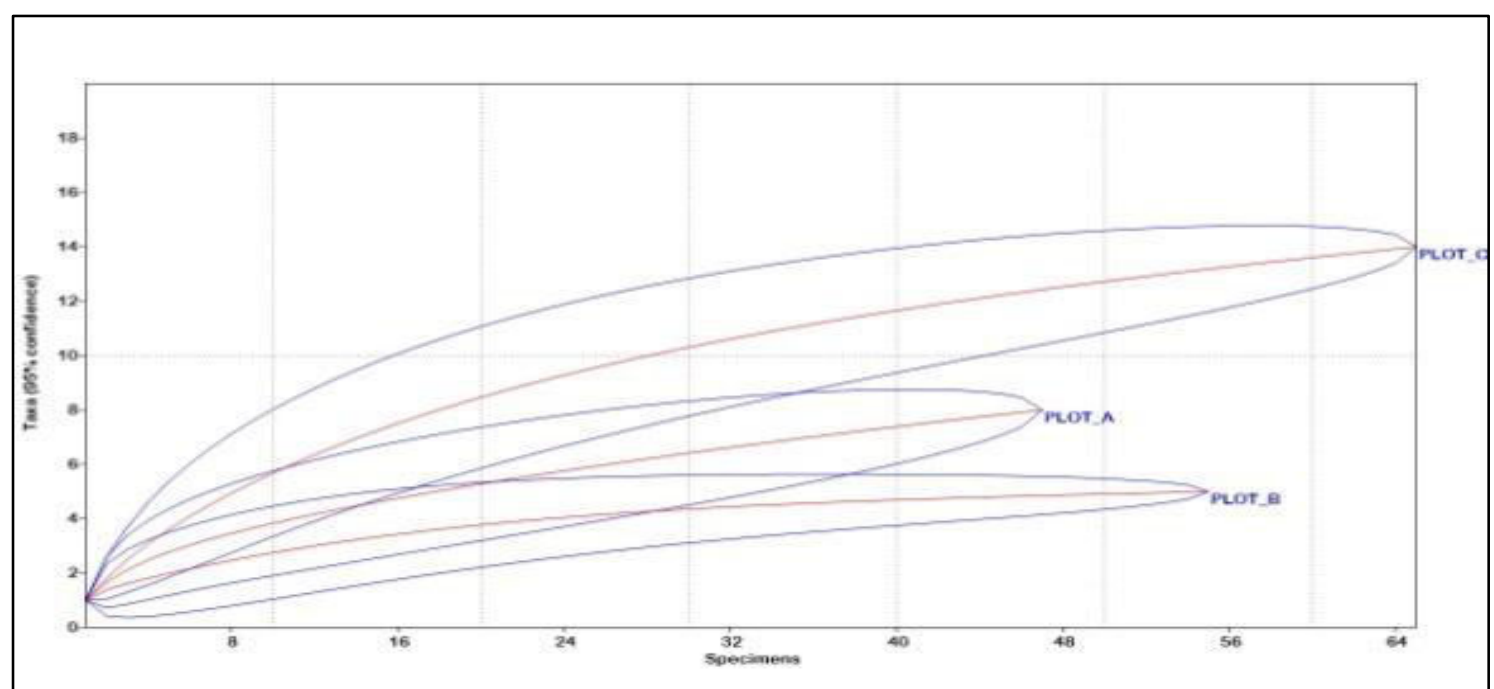

Figure 1: Rarefaction species richness curve of Fire Experimental Plot, Olokemeji Forest Reserve, Ogun State, Nigeria

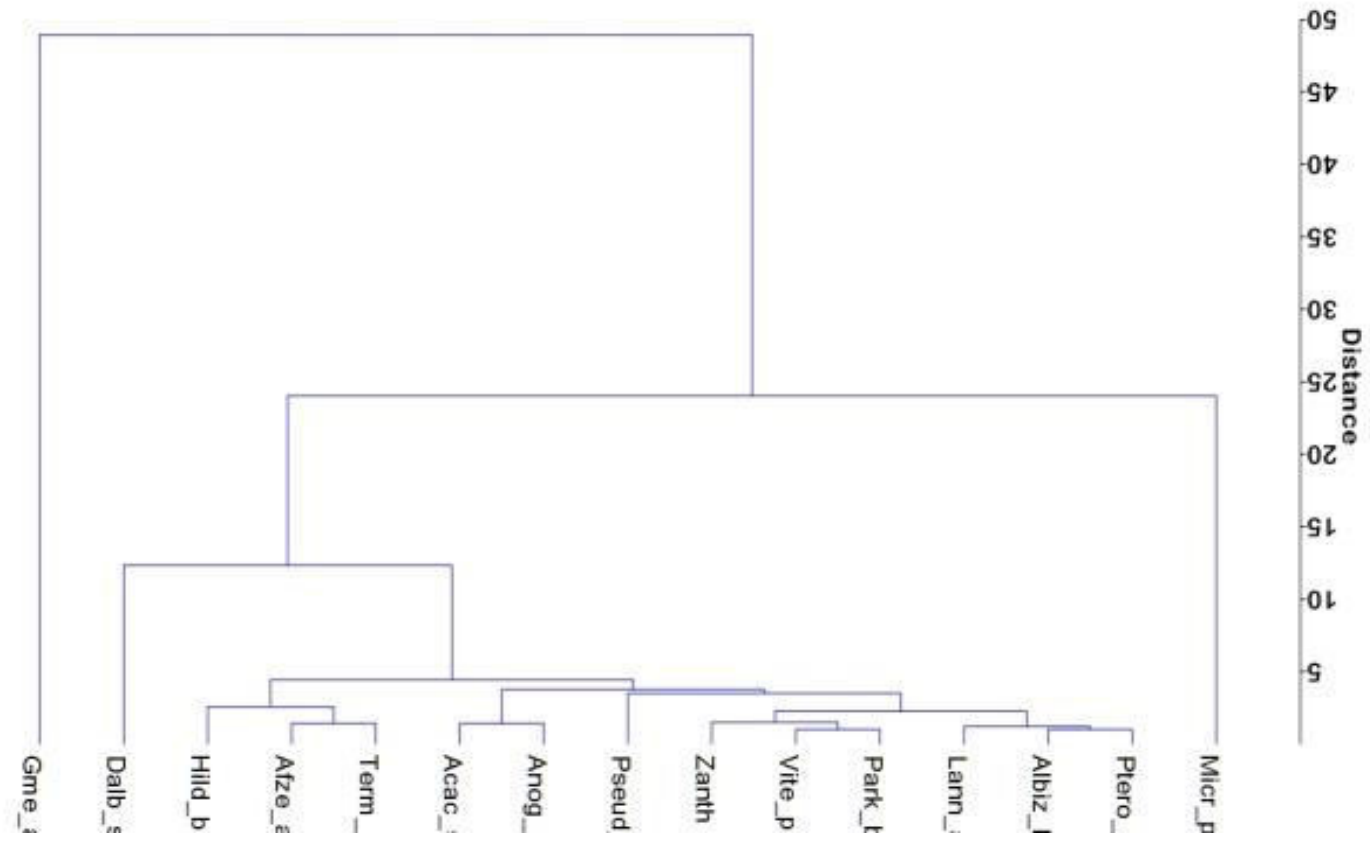

Figure 2: Cluster Dendogram of tree species of fire experimental plot, Olokemeji Forest Reserve, Ogun State, Nigeria

\section{DISCUSSION}

A total of 165 tree stands were enumerated for this study. The number of stands represents a typical characteristics of tropical rainforest and the result agrees with Akinyemi et al. (2012). Gmelina arborea stood out as a highly different species from the rest of the species assessed among the three plots.

Of the 47 tree stands in Plot A (early burning), eight species belonging to five families were found. Dominance index, Shannon or diversity index and evenness index were low, but Simpson index or species richness was moderately high probably due to loss of tree stands to death and deforestation. For Plot B, 54 species represented in three families were present. Simpson index, Shannon index and evenness index were low while Dominance index was moderately high, depicting the prevalence of Gmelina arborea in Plot B. This agrees with Akinsoji (2013) that Gmelina arborea, Anogeissus lieocarpus and Malacantha alnifolia were among the dominant trees found at fire experimental plot. Plot $\mathrm{C}$ has the highest number of tree stands as expected from the control plot protected from prescribed burning, with 64 tree stands, 13 species and 8 families. Dominance index was low as expected of a secondary regrowth forest. The highest Simpson index was recorded in Plot C. Shannon Weiner index was low in Plot $\mathrm{C}$, although it was higher than the values that were recorded for Plot $\mathrm{A}$ and Plot B. Evenness index was moderately high and relatively higher in Plot $\mathrm{C}$ than in Plot A and Plot B. 


\section{CONCLUSION}

Anthropogenic activities did not spare out Fire Experimental Plot at Olokemeji. However, some of the trees were lost as a result of natural disturbances such as pest and diseases. Gmelina aborea has proven to be fire resistant compared to other species and its abundance could be traced to its ability to regenerate itself over a long period of time. Deforestation should be strictly banned from the Fire experimental plot for the purpose of fire tracing and other field research.

\section{REFERENCES}

Adubasim C.V., Akinnibosun H.A., Dzekewong S.N. and Obalum S.E. (2018). Diversity and spatial distribution of epiphytic flora associated with four tree species of partially disturbed ecosystem in tropical rainforest zone. Agro-Science, 17 (3), 46-53. DOI: https://dx.doi.org/ 10.4314/as.v17i3.8

Akinsoji A. (2013). Vegetation development dynamics of fire experimental plots at Olokemeji Forest Reserve, Nigeria. J. Biol. Agric. Healthcare, 3 (16), 128-133

Akinyemi G.O., Ige P.O. and Smith A.S. (2012). Evaluation of crown-diameter prediction models for Terminalia superb (Engl. \& Diels) in Onigambari Forest Reserve, Nigeria. J. For. Res. Manage., 9, 37-44

Aregheore E.M. (2009). Country pasture/forage resource profiles Nigeria. Food and Agriculture Organization (FAO) of the United Nations, Rome Italy, p. 42

Attiwill P.M. (1994). The disturbance of forest eco- systems. The ecological basis for conservative management. Forest Ecol. Manage., 63, 247-300

Blondel J., Aronson J., Bodiou J-Y. and Boeuf G. (2010). The Mediterranean Region: Biological Diversity in Space and Time. Oxford Univ. Press, NY, USA. p. 54

Charter J.R. and Keay R.W.J. (1960). Assessment of the Olokemeji fire-control experiment (Investigation 254) twenty-eight years after institution. Nigerian For. lnf. Bull. (New Series) 3: Fed. Govt. Printer, Lagos

Hammer O. (2011). Paleontological Statitics Version 2.08. Natural History Museum, University of Oslo. 210 pp.

Hopkins B. (1962). Vegetation of Olokemeji Forest Reserve, Nigeria: General features of the reserve and research sites. J. Ecol., 50, 559-598

Hopper D.U., Chapin F.S., Ewel J.J. et al. (2005). Effect of biodiversity on ecosystem functioning: A consensus of current knowledge. Ecol. Monographs, 75 (1), 3-35

Innes R.R. (1915). Fire in West African vegetation land resources division, Overseas Development Admin., Tolworth Tower, Surbiton, Surrey, UK
Kent M. and Coker P. (1992). Vegetation Description and Analysis: A Practical Approach. Belhaven Press London. pp. 167-169

Lavorel S., Canadell J., Rambal S. and Terradas J. (1998). Mediterranean terrestrial ecosystems: Research priorities on global change effects. Global Ecol. Biogeo. Letters, 7, 157-166. Doi:10.2307/2997371

Lloret F. and Marí G. (2001). A comparison of medioeval and the current fire regimes in managed pine forests of Catalonia (NE Spain). For. Ecol. Manage., 141, 155-163

Magurran A.E. (2004). Measuring Biological Diversity. Blackwell Publishing, Boston. pp. 121-126

Malik Z.A. and Bhatt A.B. (2015). Phytosociological analysis of woody species in Kedarnath Wildlife Sanctuary and its adjoining areas in Western Himalaya, India. J. For. Environ. Sci., 31, 149-163

Malik Z.A., Hussain A. and Iqbal K. (2014). Species richness and diversity along the disturbance gradient in Kedarnath Wildlife Sanctuary and its adjoining areas in Garhwal Himalaya, India. Int. J. Current Res., 6, 10918-10926

Mishra A.K., Behera S.K. and Singh K. (2013). Influence of abiotic factors on community structure of understory vegetation in moist deciduous forests of north India. For. Sci. Practice, 15, 261-273

Moreira F., Ferreira P.G., Rego F.C. and Bunting S. (2001). Landscape changes and breeding bird assemblages in Northwestern Portugal: The role of fire. Landscape Ecol., 16, 175-187. Doi: 10.1023/A:1011169614489

Moreno J.M. and Oechel W.C. (1994). The role of fire in Mediterranean type ecosystems. Fire, 34, 112-120

Olubode O.S., Awodoyin R.O. and Ogunyemi S. (2011). Floral diversity in the wetlands of Apete River, Eleyele Lake and Oba Dam in Ibadan, Nigeria: Its implication for biodiversity erosion. West Afr. J. Appl. Ecol., 18, 109-119

Oluwatosin B. and Jimoh S.O. (2016). Pattern of plant species diversity in a dry forest ecosystem of Nigeria. J. For. Res. Manage., 13, 31-47

Pausas J.G. and Fernández-Muñoz S. (2012). Fire regime changes in the Western Mediterranean basin: From fuellimited to drought-driven fire regime. Climatic Change, 110 (1-2), 215-226. DOI: 10.1007/s 10584-011-0060-6

Spellerberg I.F. (1991). Monitoring Ecological Change. New York USA, Cambridge University, pp. 112-140

Stephane B., Richard C., Philippe L., Laurent B. and Frederic G. (2009). Improving biodiversity indicators of sustainable forest management: Tree genus abundance rather than tree genus richness and dominance for understory vegetation in French lowland Oak Hornbeam forests. For. Ecol. Manage., 2585, 5176-5186 